\title{
PENGARUH PENERAPAN MODEL PEMBELAJARAN PICTURE AND PICTURE YANG DIPADUKAN DENGAN STRATEGI PEMBELAJARAN AKTIF TIPE EVERYONE IS A TEACHERHERE (ETH) TERHADAP HASIL BELAJAR BIOLOGI SISWA KELAS XI MIPA SMA NEGERI 1 MUARO JAMBI
}

\author{
Armalina \\ Sekolah Menengah Atas Negeri 1 Muaro Jambi, Indonesia \\ E-mail:armalina23@gmail.com
}

\begin{abstract}
This study aims to analyze the influences of picture and picture'smodel implementation that integrated with the learning strategic active type of everyone is a teacher here (ETH) on students' learning result o biology for students at XI class MIPA SMA NEegeri 1 Muaro Jambi. This study employed experiment research by using the posttest-only control design. The data consist of quantitative and qualitative data.The result of study shows that the integrated of picture and picture learning model and active learning the everyone is a teacher here (ETH) have an influenceon biology leraning result for students calss XI MIPA SMA Negeri 1 Muaro Jambi cognitive area thas is $\mathrm{t}_{\text {hitung }}=4,55$ and $\mathrm{t}_{\text {tabel }}=1,671$.
\end{abstract}

Keywords: students' learning result,picture and picture model, Everyone is a teacher here (ETH)

\section{Pendahuluan}

Pendidikan merupakan salah satu faktor yang berperan penting didalam berkembangnya suatu negara. Pendidikan memegang fungsi yang sangat erat dalam meningkatkan kualitas Sumber Daya Manusia (SDM). Apabila sumber daya manusia meningkat, maka akan memberikan suatu dampak yang baik terhadap kemajuan negaranya. Salah satu instansi pendidikan yang berada di sekitar masyarakat adalah sekolah. Menurut Triwiyanto (2014:22), pendidikan dalam arti sempit adalah sekolah. Pendidikan adalah pengajaran yang diselenggarakan disekolah sebagai lembaga formal. Pendidikan adalah segala pengaruh yang diupayakan sekolah terhadap anak dan remaja yang diserahkan oleh orangtu/wali kepadanya agar mempunyai kemampuan yang sempurna dan kesadaran penuh terhadap hubungan-hubungan dan tugas-tugas sosial mereka.

Sekolah berperan sebagai tempat terjadinya proses pembelajaran. Pembelajaran merupakan proses kegiatan belajar mengajar antara peserta didik dengan tenaga pendidik dan sumber belajar. Melalui proses pembelajaran, seorang guru dituntut untuk dapat membimbing peserta didik kearah yang lebih baik. Proses pembelajaran yang baik akan menghasilkan hasil belajar yang baik juga. Setiap perilaku yang terjadi pada saat terjadinya proses pembelajaran akan mempengaruhi setiap perkembangan pengetahuan, sikap dan keterampilan peserta didik. 
Dalam proses pembelajaran, guru berperan sebagai sumber belajar, fasilitator dan motivator. Seorang guru harus mampu membangkitkan motivasi peserta didik dalam belajar. Guru mempunyai peran besar didalam membimbing peserta didik dalam hal perkembangan pengetahuan, keterampilan dan sikap peserta didik. Seorang guru harus mampu merangsang pemikiran siswa untuk semakin aktif dan kreatif. Hal ini akan berpengaruh terhadap perkembangan kemampuan anak. Untuk dapat mewujudkan peran guru tersebut, menurut Ngalimun seorang guru dituntut untuk memiliki kemampuan mengatur secara umum komponen-komponen sedemikian rupa sehingga terjalin keterkaitan fungsi antara isi komponen pengajaran tersebut atau dalam bahasa lain disebutkan sebagai strategi pembelajaran. (Ngalimun, 2014, p.1) Strategi berarti pilihan/ pola dalam kegiatan belajar mengajar yang digunakan untuk mencapai tujuan pembelajaran yang efektif. Dengan demikian akan mencapai hasil belajar yang maksimal.

Hasil belajar merupakan suatu perubahan yang terjadi akibat adanya pengajaran. Hasil belajar siswa sangat dipengaruhi diantaranya adalah karakteristik siswa, sikap belajar siswa, motivasi belajar, rasa percaya diri dan kebiasaan belajar. Keberhasilan hasil belajar bermuara pada seluruh aktivitas yang dilakukan oleh guru dan siswa dalam proses pembelajaran, maka setiap guru harus mampu berupaya secara optimal memahami berbagai faktor yang dapat menghambat proses pembelajaran. (Aunurrahman, 2013, p.199)

Berdasarkan hasil wawancara dengan guru Biologi kelas XI SMA Negeri 1 Muaro Jambi didapatkan bahwa untuk saat ini proses pembelajaran yang dilakukan di sekolah tersebut merupakan pembelajaran satu pihak, dimana siswa kurang aktif didalam pembelajaran. Siswa hanya mengharapkan dan menerima semua pembelajaran dari guru dan sebagian siswa didapatkan mempunyai kemampuan rendah didalam mengemukakan pendapat. Hal ini tentu saja mengakibatkan hasil belajar rendah. Hasil belajar tersebut berada dibawah nilai KKM yang telah ditetapkan oleh sekolah yaitu sebesar 67 .

Tabel 1 Nilai rata-rata siswa kelas XI MIPA SMA Negeri 1 Muaro Jambi.

\begin{tabular}{|c|c|c|}
\hline No & Kelas & Nilai Rata-Rata \\
\hline 1. & XI MIPA-1 & 58,6 \\
\hline 2. & XI MIPA-2 & 62,5 \\
\hline 3. & XI MIPA-3 & 60 \\
\hline 4. & XI MIPA-4 & 61 \\
\hline 5. & XI MIPA-5 & 59,1 \\
\hline 6. & XI MIPA-6 & 59,3 \\
\hline 7. & XI MIPA-7 & 60 \\
\hline
\end{tabular}

Sumber: Dokumen Guru Biologi Kelas XI SMA Negeri 1 Muaro Jambi

Rendahnya kemampuan siswa dalam mengemukakan pendapat dapat diatasi dengan diadakannya pembelajaran yang menarik. Dimana pembelajaran yang dimaksud diharapkan memberikan suatu dampak yang positif terhadap anak. Dengan dilakukannya pembelajaran yang menarik diharapkan pembelajaran tidak lagi dilakukan dengan dengan satu arah. Artinya siswa tidak hanya mengharapkan 
semua informasi dari guru saja namun diharapkan akan dapat membagikan informasi yang telah mereka ketahui kepada guru maupun kepada teman temannya. Untuk dapat mewujudkan pembelajaran yang demikian, maka guru harus mampu memberikan pengajaran dengan model pembelajaran dengan memadukan berbagai strategi pembelajaran.

Suatu pembelajaran tentu tidak terlepas dari komponen pembelajaran. Komponen pembelajaran terdiri dari model pembelajaran, strategi pembelajaran dan lain-lain. Menurut Joyce dalam Majid, model pembelajaran merupakan suatu perencanaan atau pola yang digunakan sebagai pedoman dalam marencanakan pembelajaran di kelas atau pembelajaran dalam tutorial untuk menentukan perangkat perangkat pembelajaran. (Abdul Majid, 2014, p.13-14) Strategi pembelajaran juga diartikan sebagai suatu rencana tindakan (rangkaian kegiatan) yang termasuk penggunaan metode dan pemanfaatan berbagai sumber daya atau kekuatan dalam suatu pembelajaran.

Seorang guru dituntut untuk melakukan perbaikan dalam proses pembelajaran. Salah satu alternatif dalam pemecahan masalah ini penulis menerapkan model pembelajaran Picture and Picture dipadukan dengan strategi pembelajaran aktif tipe Everyone Is A Teacher Here (ETH) untuk melatih siswa di dalam memahami pembelajaran serta membantu siswa untuk dapat mengemukakan pendapat. Dengan adanya model pembelajaran dan strategi pembelajaran, guru dapat membantu peserta didik untuk mendapatkan informasi dan mendorong siswa untuk berpartisipasi didalam pembelajaran sehingga akan berdampak pada peningkatan hasil belajar.

Model pembelajaran Picture and Picture merupakan model pembelajaran yang menarik dalam menyajikan materi karena adanya penggunaan gambar di setiap pernyajian materi namun disisi lain membuat siswa menjadi kurang aktif. Berbeda dengan Strategi Pembelajaran ETH merupakan strategi pembelajaran yang mendorong siswa untuk lebih aktif didalam proses pembelajaran namun kurang menarik dalam penyajian materi ajar. Peneliti memilih Model pembelajaran Picture and Picture dipadukan dengan Strategi Pembelajaran ETH diharapkan mampu untuk saling melengkapi kekurangan dari masing masing.

Penelitian ini bertujuan untuk mengetahui penerapan model pembelajaran Picture and Picture yang dipadukan dengan strategi pembelajaran aktif tipe Everyone Is A Teacher Here (ETH) berpengaruh terhadap hasil belajar biologi pada ranah kognitifsiswa kelas XI MIPA SMA Negeri 1 Muaro Jambi.

\section{Teori Belajar}

Menurut Gagne dalam Susanto belajar dapat didefenisikan sebagai proses di mana suatu organisme berubah perilakunya sebagai akibat pengalamannya. Belajar dan mengajar merupakan dua konsep yang tidak dapat dipisahkan satu sama lain. (Ahmad,Susanto, 2013, p.1) Dua konsep ini menjadi terpadu dalam satu kegiatan dimana terjadi interaksi antara guru dengan siswa, serta siswa dengan siswa pada saat pembelajaran berlangsung. Menurutnya, belajar juga dimaknai sebagai suatu proses untuk memperoleh motivasi dalam pengetahuan, keterampilan, kebiasaan dan tingkah laku. Belajar merupakan suatu upaya memperoleh pengetahuan atau keterampilan melakui instruksi. Instruksi yang 
dimaksud adalah perintah atau arahan dan bimbingan dari seseorang pendidik atau guru.

Defenisi belajar mencakup tiga unsur yaitu (1) belajar adalah perubahan tingkah laku, (2) perubahan tingkah laku tersebut terjadi karena latihan atau pengalaman, (3) perubahan tingkah laku tersebut relatif permanen atau tetap ada untuk waktu yang cukup lama. (Aunurrahman, 2013, p.48) Belajar dimulai dengan adanya dorongan, semangat, dan upaya yang timbul dalam diri seseorang sehingga orang itu melakukan kegiatan belajar. Kegiatan belajar yang dilakukan menyesuaikan dengan tingkah lakunya dalam upaya meningkatkan kemampuan dirinya. Dalam hal ini, belajar adalah perilaku mengembangkan diri melalui proses penyesuaian tingkah laku. Penyesuaian tingkah laku dapat terwujud melalui kegiatan belajar. Belajar sebagai proses dapat dikatakan sebagai kegiatan seseorang yang dilakukan dengan sengaja melalui penyesuaian tingkah laku dirinya dalam upaya meningkatkan kualitas kehidupannya. (Abdul Majid, 2014, p.33)

Menurut Aunurrahman ada tiga ciri umum dari kegiatan pembelajaran yaitu: (Aunurrahman, 2013, p.36)

1) Belajar menunjukkan sesuatu aktivitas pada diri seseorang yang didasari atau disengaja. Oleh sebab itu pemahaman kita pertama yang sangat penting adalah bahwa kegiatan belajar pembelajaran sendiri dalam bentuk suatu aktivitas tertentu.

2) Belajar merupakan interaksi individu dengan lingkungannya. Lingkungan dalam hal ini dapat berupa manusia atau obyek-obyek lain yang memungkinkan individu memperoleh pengalaman-pengalaman atau pengetahuan baik pengalaman atau pengetahuan baru maupun sesuatu yang pernah diperoleh atau ditemukan sebelumnya akan tetapi menimbulkan perhatian kembali bagi individu tersebut sehinggga memungkinkan terjadinya interaksi.

3) Hasil belajar ditandai dengan perubahan tingkah laku. Walaupun tidak semua perubahan tingkah laku merupakan hasil belajar, akan tetapi aktivitas belajar umumnya disertai dengan perubahan tingkah laku.

Secara umum, kelompok teori yang memberikan pandangan khusus tentang belajar diantaranya adalah:

\section{Teori Belajar Behaviorisme}

Aliran ini disebut dengan behaviorisme karena sangat menekankan kepada perlunya perilaku (behavior) yang dapat diamati. Ada beberapa ciri dari rumpun teori ini yaitu: (1) mengutamakan unsur-unsur atau bagian-bagian kecil, (2) bersifat mekanistis, (3) menekankan peranan lingkungan, (4) mementingkan pembentukan respon, (5) menekankan pentingnya latihan. Pembelajaran behaviorisme bersifat molekuler, artinya lebih menekankan kepada elemenelemen pembelajaran, memandang kehidupan individu terdiri dari unsur-unsur seperti halnya molekul. (Suyono \& Hariyanto, 2014, p.58)

Sebagaimana pada kebanyakan aliran psikologi belajar lainnya, behaviorisme juga melihat bahwa belajar merupakan perubahan tingkah laku. Ciri yang paling mendasar dari aliran ini adalah bahwa perubahan tingkah laku yang terjadi adalah berdasarkan paradigma S-R (Stimulus Respons), yaitu suatu proses 
yang memberikan respon tertentu terhadap sesuatu yang datang dari luar. Proses ini terdiri dari beberapa unsur dorongan (drive). Pertama seseorang merasakan adanya kebutuhan akan sesuatu dan terdorong untuk memenuhi kebutuhan tersebut. Kedua, rangsangan atau stimulus dimana seseorang yang diberikan stimulus menyebabkannya memberikan respon. Ketiga, respon dimana seseorang memberikan reaksi atau respon terhadap stimulus yang diterimanya dengan melakukannya dengan suatu tindakan yang dapat diamati. Keempat, unsur penguatan atau reinforcement, yang perlu diberikan kepada seseorang agar merasakan adanya kebutuhan untuk memberikan respon lagi. (Aunurrahman, 2013, p.39)

\section{Teori Pembelajaran Kognitivisme}

Teori belajar kognitivisme berasal dari pandangan kurt Lewin dalam Fatmawati,dkk. menyatakan bahwa belajar merupakan proses penemuan (discovery) dan transformasi informasi kompleks yang berlangsung pada diri seseorang. (Fatmawati Sri, Ariesta, Darmaji \& Putri, 2015, p.6) Teori kognitivisme menekankan pada bagaimana informasi diproses oleh peserta didik dan disimpan dalam memorinya dalam bentuk pengetahuan utuh. Peserta didik atau individu yang sedang belajar dipandang sebagai orang yang akan mengkonfirmasi informasi baru yang didapat dan proses pembelajaran dengan prinsip yang telah dimiliki, kemudian merevisi prinsip tersebut apabila sudah tidak sesuai dengan informasi yang baru diperoleh agar peserta didik mampu melakukan kegiatan belajar, maka ia harus melibatkan diri secara aktif.

Salah satu tokoh yang mengembangkan Teori kognitivisme adalah Gestalt yang menyatakan bahwa jiwa manusia adalah keseluruhaan yang berstruktur. Suatu keseluruhan bukan terdiri dari bagian-bagian atau unsur-unsur. Unsur-unsur itu berada dalam keseluruhan menurut struktur yang telah tertentu dan saling berinteraksi satu sama lain. (Oemar Hamalik, 2005, p.47) Teori kognitivisme menganggap bahwa belajar sebuah proses mental, bukan behavioral. Dalam teori ini, peserta didik aktif sebagai penyadur, belajar secara individu dengan pola deduktif dan induktif. Sedangkan guru berlaku sebagai fasilitator dalam pembelajaran. Menurut teori ini peserta didik memiliki motivasi instrinsik sehingga tidak perlu stimulus untuk merangsang aktivitas dalam pembelajaran. (Fatmawati Sri, Ariesta, Darmaji \& Putri, 2015, p.7)

\section{Teori Pembelajaran Kontruktivisme}

Pada pertengahan abad ke 20, Piaget mengembangkan sebuah teori pembelajaran yang dikenal dengan teori pembelajaran konstruktivisme. Teori pembelajaran tersebut menyatakan bahwa pada dasarnya setiap individu sejak kecil sudah memiliki kemampuan untuk mengkonstruksi pengetahuan sendiri. Pengetahuan yang dikontruksi oleh anak sebagai subjek, maka akan menjadi pengetahuan yang bermakna. Sedangkan pengetahuan yang hanya diperoleh melalui proses pemberitahuan tidak akan menjadi pengetahuan yang bermakna. Pengetahuan tersebut hanya untuk diingat sementara setelah itu dilupakan. (Wina Sanjaya, 2006, p.124)

Menurut paham konstruktivisme, ilmu pengetahuan disekolah tidak dipindahkan dari guru ke siswa dalam bentuk serba sempurna. Siswa perlu memberi suatu pengetahuan mengikuti pengalaman masing-masing. Pembelajaran 
adalah hasil usaha siswa itu sendiri. Teori konstruktivisme mengedepankan bahwa pembelajar atau siswa mengkonstruksi pengetahuan meraka diatas pengetahuan awal yang telah diperoleh sebelumnya. Siswa aktif dalam melakukan kegiatan dan aktif berfikir. Dengan kata lain, siswa mengkonstruksi pengetahuan mereka, menyusun konsep, dan memberikan makna peluang optimal bagi terjadinya proses belajar. Jadi, yang menentukan terwujudnya gejala belajar adalah niat belajar siswa sendiri. Dengan demikian. teori konstruktivisme ini mendukung pentingnya sikap, motivasi dan konsep pribadi siswa dalam proses belajar mandiri. (Wicaksono Andri, Syaefudin Mohamad, Qalbi Nur, Nasir Mohamad, 2016, p.432)

\section{Teori Pembelajaran Humanistik}

Humanisme adalah aliran pemikiran yang menyakini bahwa makhluk manusia berbeda dari spesies lainnya dan memiliki kapasitas-kapasitas yang tidak terdapat pada hewan lainnya. Oleh karenanya, para humanis memberikan penekanan kepada perlunya kajian tentang kebutuhan dan minat manusia. Para psikolog humanis dikenali karena melihat para siswa sebagai seseorang yang mampu dan memiliki kebebasan untuk mengambil inisiatif dan mengembangkan tujuan pembelajarannya sendiri, yang dilihatnya relevan dengan kebutuhan dan minat mereka. (Warsono\&Hariyanto, 2012, p.65)

Dalam teori belajar humanistik proses belajar harus berhulu dan bermuara pada manusia itu sendiri. Meskipun teori ini sangat menekankan pentingnya isi dari proses belajar, dalam kenyataan teori ini lebih banyak berbicara tentang pendidikan dan proses belajar dalam bentuknya yang paling ideal. Teori apapun dapat dimanfaatkan asalkan bertujuan untuk memanusiakan manusia (mencapai aktualisasi dan sebagainya). Menurut teori belajar humanistik, belajar dianggap berhasil jika si pelajar memahami lingkungannya dan dirinya sendiri. Siswa dalam proses belajarnya harus berusaha agar lembat laun mampu mencapai aktualisasi dirinya dengan sebaik-baiknya. Teori belajar ini berusaha memahami perilaku belajar dari sudut pandang pelakunya, bukan dari sudut pandang pengamatnya. (Suardi, 2015, p. 171-172)

\section{Teori Pembelajaran Psikologi Sosial}

Pandangan psikologi sosial secara mendasar mengungkapkan bahwa belajar pada hakikatnya merupakan suatu proses yang alami. Hal ini pada dasarnya disebabkan karena setiap orang memiliki rasa ingin tahu, ingin menyerap informasi, ingin mengambil keputusan serta ingin memecahkan masalah. Menurut teori belajar psikologi sosial proses belajar merupakan proses yang terjadi dalam keadaan menyendiri, akan tetapi melalui berbagai interaksi. Interaksi tersebut dapat berupa ; (1) searah (one directional), yaitu bilamana adanya stimuli dari luar menyebabkan timbulnya respons, (2) dua arah, yaitu apabila tingkah laku yang terjadi merupakan hasil interaksi antara individu yang belajar dengan lingkunganya atau sebaliknya. (Aunurrahman, 2013, p.46)

\section{Teori Belajar Gagne}

Teori belajar yang disusun Gagne merupakan perpaduan yang seimbang antara behaviorisme dan kognitivisme yang berpangkal pada teori pengelolahan informasi. Menurut Gagne cara berpikir seseorang tergantung pada: (1) keterampilan apa yang dimilikinya, (b) keterampilan serta hirarki apa yang 
diperlukan untuk mempelajari satu tugas. Dengan demikian menurut Gagne didalam proses belajar terdapat dua fenomena, yaitu: meningkatnya keterampilan intelektual sejalan dengan meningkatnya umur serta latihan yang diperoleh individu, dan belajar akan lebih cepat bilamana strategi kognitif dapat dipakai dalam memecahkan masalah secara lebih efisien. (Aunurrahman, 2013, p.46-47) Gagne dalam Daryanto menyatakan bahwa ada 5 kategori dalam belajar atau yang dikenal dengan domains of learning, diantaranya adalah: (Daryanto, 2010, p.1213)

1) Keterampilan motoris (motor skill)

Dalam hal ini perlu koordinasi dari berbagai gerakan badan, misalnya melemparkan bola, main tenis, mengemudi mobil, mengetik huruf dan sebagainya.

2) Informasi verbal

Orang dapat menjelaskan sesuatu dengan berbicara, menulis menggambar, dalam hal ini dapat dimengerti bahwa untuk mengatakan sesuatu ini perlu intelegensi.

3) Kemampuan intelektual

Manusia mengadakan interaksi dengan dunia luar dengan menggunakan simbol-simbol. Kemampuan belajar cara inilah yang disebut kemampuan intelektual, misalnya membedakan huruf $\mathrm{m}$ dan $\mathrm{n}$, menyebut tanaman yang sejenis.

4) Strategi kognitif

Kemampuan mengingat berbeda dengan kemampuan intelektual karena ditujukan kedunia luar, dan tidak dapat dipelajari hanya dengan berbuat satu kali serta memerlukan perbaikan-perbaikan secara terus-menerus.

5) Sikap

Kemampuan ini tidak dapat dipelajari dengan ulangan-ulangan, tidak tergantung atau dipengaruhi oleh hubungan verbal seperti halnya domain yang lain, sikap ini penting dalam proses belajar, tanpa kemampuan ini belajar tidak akan berhasil dengan baik.

\section{Model Pembelajaran}

Model pembelajaran merupakan landasan praktik pembelajaran hasil penurunan teori psikologi pendidikan dan teori belajar. Model pembelajaran dirancang berdasarkan analisis terhadap implementasi kurikulum dan implikasinya pada tingkat operasional di kelas. Secara spesifik, model pembelajaran diartikan sebagai pola yang digunakan untuk penyusunan kurikulum, mengatur materi dan memberikan petunjuk kepada guru di kelas. Melalui model pembelajaran guru dapat membantu peserta didik untuk mendapatkan informasi, ide, keterampilan, cara berpikir serta cara mengekpresikan. Hal ini diakibatkan adanya fungsi model pembelajaran sebagai pedoman guru didalam merangcang aktivitas dikelas. (Agus Suprijono, 2015, p.64)

Model pembelajaran mempunyai makna yang lebih luas dari pendekatan, strategi, metode dan teknik. Karena itu, suatu rancangan pembelajaran atau rencana pembelajaran disebut menggunakan model pembelajaran apabila mempunyai ciri khusus, yaitu rasional teoritik yang logis, landasan pemikiran 
tentang bagaimana siswa belajar, tingkah laku, dan lingkungan belajar. Selain itu, suatu model pembelajaran juga akan memuat tentang deskripsi lingkungan belajar, pendekatan, metode dan teknik, strategi, media, materi pembelajaran, serta desain pembelajaran dan juga manfaat pembelajaran. (Ngalimun, 2014, p.29)

Istilah model pembelajaran mempunyai makna yang lebih luas daripada strategi, metode atau prosedur pengajaran. Model pembelajaran berfungsi sebagai pedoman bagi pengajar dan para guru dalam melaksanakan pembelajaran. Hal ini menunjukkan bahwa setiap model yang akan digunakan dalam pembelajaran menentukan perangkat pembelajaran yang akan dipakai dalam pembelajaran tersebut. (Aris Shoimin, 2014, p.122)

Berdasarkan pengertian model pembelajaran yang dikemukakan oleh para ahli diatas, maka secara garis besar model pembelajaran adalah suatu rancangan pembelajaran yang dilakukan oleh guru didalam kegiatan pembelajaran dari awal hingga akhir pembelajaran. Model pembelajaran tersebut diharapkan dapat membantu siswa didalam mencapai hasil belajar yang maksimal. Dengan penerapan model pembelajaran yang menarik diharapkan akan berdampak kepada hasil pencapaian siswa.

\section{Model Pembelajaran Picture and Picture}

Model pembelajaran Picture and Picture adalah suatu model belajar dengan menggunakan gambar dan dipasangkan atau diurutkan menjadi urutan logis. Model pembelajaran ini mengandalkan gambar yang menjadi faktor utama dalam proses pembelajaran. Maka dari itu, sebelumnya guru sudah menyiapkan gambar yang akan ditampilkan, baik dalam bentuk kartu ataupun carta dalam ukuran besar. Gambar sangat penting digunakan untuk memperjelas pengertian. Melalui gambar, siswa mengetahui hal-hal yang belum pernah dilihatnya. (Aris Shoimin, 2014, p.122)

\section{Langkah-Langkah Model Pembelajaran Picture and Picture}

Menurut Suprijono langkah-langkah dalam melakukan model pembelajaran Picture and Picture yaitu: (Agus Suprijono, 2015, p.144-145)

1. Guru menyampaikan kompetensi yang ingin dicapai.

2. Guru menyajikan materi sebagai pengantar.

3. Guru memperlihatkan gambar-gambar kegiatan berkaitan dengan materi.

4. Guru menunjukkan/memanggil siswa secara bergantian memasang /mengurutkan gambar-gambar menjadi urutan yang logis.

5. Dari gambar tersebut guru memulai menanamkan konsep/materi sesuai dengan kompetensi yang ingin dicapai.

6. Kesimpulan atau rangkuman.

\section{Strategi Pembelajaran Aktif}

Belajar aktif salah satu cara yang diterapkan untuk mengikat informasi baru kemudian menyimpannya di dalam otak. Belajar aktif sangat diperlukan oleh peserta didik untuk mendapatkan hasil belajar yang maksimun. Ketika peserta didik pasif, dimana peserta didik hanya mau menerima apa yang diajarkan oleh gurunya terdapat, maka akan berakibat adanya kecenderungan untuk cepat melupakan apa yang telah diberikan. Oleh karena itu diperlukan perangkat tertentu untuk dapat mengikat informasi dan baru kemudian meyimpannya didalam otak. (Zaini Hisyam, Munthe Bermawy, Aryani Ayu Sekar, 2008, p.1) 
Pembelajaran aktif merupakan suatu pembelajaran yang mengajak peserta didik untuk belajar secara aktif. ketika peserta didik mampu belajar secara aktif maka peserta didiklah yang mendominasi pembelajaran bukan guru. (Zaini Hisyam, Munthe Bermawy, Aryani Ayu Sekar, 2008, p.1) Berdasarkan penjelasan diatas mengenai belajar aktif dan pembelajaran aktif dapat disimpulkan bahwa strategi pembelajaran aktif merupakan suatu cara yang diterapkan oleh tenaga pengajar dalam proses pembelajaran yang melibatkan siswa secara aktif. Dalam hal ini guru tidak lagi menjadi sumber utama informasi belajar, namun siswa harus dapat melibatkan dirinya didalam menemukan informasi baru sehingga peserta didik tidak lagi dengan mudah melupakan hal hal yang disampaikan dalam proses pembelajaran.

Menurut Uno ciri-ciri dari strategi pembelajaran aktif adalah sebagai berikut: (Hamzah Uno, 2014, p.76)

1) Pembelajaran terkait dengan kehidupan nyata. Pembelajaran mendorong anak untuk berpikir tinggi.

2) Pembelajaran melayani gaya belajar anak yang berbeda-beda.

3) Pembelajaran mendorong anak untuk berinteraksi multiarah (siswa-guru).

4) Pembelajaran menggunakan lingkungan sebagai media atau sumber belajar.

5) Pembelajaran berpusat pada anak.

6) Penataan lingkungan belajar memudahkan siswa untuk melakukan kegiatan belajar.

7) Guru memantau proses siswa

8) Guru memberikan umpan balik terhadap hasil kerja siswa.

\section{Strategi Pembelajaran Everyone Is A Teacher Here (ETH)}

Everyone Is A Teacher Here (ETH) merupakan salah satu strategi pembelajaran aktif yang sering digunakan oleh guru dalam proses pembelajaran. Strategi ini mempunyai bahasa lain yaitu "Semua Orang Disini Adalah Guru". Strategi pembelajaran ETH merupakan sebuah strategi yang mudah guna memperoleh partisipasi kelas yang besar dan tanggung jawab induvidu. Strategi ini memberikan kesempatan kepada setiap peserta didik untuk bertindak sebagai seorang pengajar terhadap peserta didik lain. (Mel Silberman, 2009,p.142)

Strategi pembelajaran ETH adalah salah satu jenis strategi pembelajaran aktif. Strategi ini memberikan kesempatan kepada setiap peserta didik untuk berperan sebagai guru bagi teman temannya. Dengan penggunaan strategi ini diharapkan peserta didik yang selama ini tidak mau terlibat akan ikut serta dalam proses pembelajaran secara aktif.

\section{Langkah Langkah Strategi Pembelajaran ETH}

Menurut Silberman langkah langkah penerapan strategi pembelajaran ETH adalah :

1. Guru membagikan kartu indeks kepada setiap siswa dan meminta seluruh siswa untuk menuliskan pertanyaan tentang materi yang sedang diperlajari dikelas.

2. Guru mengumpulkan semua kartu, kemudian mengocoknya. 
3. Guru membagikannya ke setiap siswa dan memastikan jika kartu yang mereka terima bukan kartu yang meraka tulis sebelumnya.

4. Guru meminta siswa untuk membaca dalam hati pertanyaan atau topik yang tercantum di kartunya dan memikirkan jawabannya.

5. Guru meminta beberapa siswa secara sukarela untuk membacakan tulisan di kartunya dengan suara keras dan menyampaikan jawabannya.

6. Setelah jawaban diberikan, maka guru meminta siswa yang lain untuk menambahi jawaban tersebut dengan pendapat mereka sendiri.

7. Penutup.

\section{Taksonomi Hasil Belajar}

\section{Taksonomi Hasil Belajar Kognitif}

Hasil belajar kognitif adalah perubahan perilaku yang terjadi dalam kawasan kognisi. Proses belajar yang melibatkan kognisi meliputi kegiatan sejak dari penerimaan stimulus eksternal oleh sensori, penyimpanan dan pengolahan dalam otak menjadi informasi hingga pemanggilan kembali informasi ketika diperlukan untuk menyelesaikan masalah. Oleh karena itu, belajar melibatkan otak, maka perubahan perilaku akibatnya juga terjadi dalam otak berupa kemampuan tertentu oleh otak untuk menyelesaikan masalah. (Purwanto, 2014, p.50)

Uno dan Mohamad membagi dan menyusun secara hirarkis tingkat hasil belajar kognitif mulai dari yang paling rendah dan sederhana yaitu hapalan sampai yang paling tinggi dan kompleks yaitu evaluasi. (Hamzah Uno, 2014, p.56-67) Enam tingkatan tersebut yaitu hafalan (C1), pemahaman (C2), penerapan (C3), analisis (C4), sintesis (C5), dan evaluasi (C6). Untuk penjelasan lebih lanjut diuraikan sebagai berikut:

1. Kemampuan menghafal (knowledge) merupakan kemampuan seseorang dalam menghafal, mengingat kembali atau mengulang kembali pengetahuan yang pernah diterimanya.

2. Kemampuan pemahaman (comprehension) adalah kemampuan seseorang dalam mengartikan, menafsirkan, menerjemahkan atau menyatakan sesuatu dengan caranya sendiri tentang pengetahuan yang pernah diterimanya.

3. Kemampuan penerapan (application) adalah kemampuan seseorang dalam menggunakan pengetahuan dalam memecahkan berbagai masalah yang timbul dalam kehidupan sehari-hari.

4. Kemampuan analisis (analisis) diartikan sebagai kemampuan seseorang dalam menggunakan pengetahuan dalam memecahkan berbagai masalah yang timbul dalam kehidupan sehari-hari.

5. Kemampuan sistesis (synthesis) adalah kemampuan seseorang dalam mengaitkan dan menyatukan berbagai elemen dan unsur pengetahuan yang ada sehingga terbentuk pola baru yang lebih menyeluruh.

6. Kemampuan evaluasi (evaluation) adalah kemampuan seseorang dalam membuat perkiraan atau keputusan yang tepat berdasarkan kriteria atau pengetahuan yang dimilikinya. 


\section{Hipotesis}

$\mathrm{H}_{0} \quad$ : Penerapan model pembelajaran Picture and Picture yang dipadukan dengan strategi pembelajaran Everyone Is A Teacher Here tidak berpengaruh terhadap hasil belajar biologi siswa pada ranah kognitif.

$\mathrm{H}_{1}$ : Penerapan model pembelajaran Picture and Picture yang dipadukan dengan strategi pembelajaran Everyone Is A Teacher Here berpengaruh Metode terhadap hasil belajar biologi siswa pada ranah kognitif.

Jenis penelitian yang akan digunakan dalam penelitian ini adalah jenis penelitian eksperimen. Penelitian eksperimen adalah suatu penelitian yang didasarkan dengan adanya suatu peristiwa dapat diketahui penyebab terjadinya masalah tersebut. Menurut Gulo penelitian eksperimen merupakan peristiwa yang diteliti sudah terjadi sehinggga data-datanya dapat dilacak kembali melalui kuesioner atau dokumen-dokumen yang relevan. (W Gulo, 2000, p.20) Kelompok yang diberi perlakukan disebut kelas eksperimen sementara kelas yang tidak diberi perlakuan disebut kelas kontrol.

Penelitian ini menggunakan The Posttest-Only Control Design. Menurut Sugiyono dalam The Posttest-Only Control Design terdapat dua kelompok yang masing-masing dipilih secara random (R). (Sugiyono, 2014, p.112) Kelompok pertama diberi perlakuan $(\mathrm{X})$ dan kelompok yang lain tidak. Kelompok yang diberi perlakuan disebut kelompok eksperimen dan kelompok yang tidak diberi perlakukan disebut kelompok kontrol.

Pada penelitian ini kelompok pertama diberi perlakuan (X) berupa penerapan model pembelajaran Picture and Picture yang dipadukan dengan strategi pembelajaran Everyone Is A Teacher Here dan kelompok kedua tidak dilakukannya penerapan model pembelajaran Picture and Picture yang dipadukan dengan strategi pembelajaran Everyone Is A Teacher Here. Kelompok yang diberi perlakuan disebut dengan kelompok eksperimen dan kelompok yang tidak diberi perlakuan disebut kelompok kontrol.

Tabel 2 Rancangan Penelitian

\begin{tabular}{|c|c|c|}
\hline Kelompok & Perlakuan & Tes Akhir (Posttest) \\
\hline Kelas eksperimen & $\mathrm{X}$ & $\mathrm{T} 1$ \\
\hline Kelas Kontrol & - & $\mathrm{T} 2$ \\
\hline
\end{tabular}

Keterangan :

$\mathrm{X}$ : Pembelajaran dengan menggunakan model pembelajaran Picture and Picture yang dipadukan dengan Strategi pembelajaran $E T H$

$\mathrm{T}_{1}$ : Tes akhir kelas eksperimen

$\mathrm{T}_{2}$ : Tes akhir kelas kontrol

Populasi dalam penelitian ini adalah peserta didik kelas XI MIPA SMA Negeri 1 Muaro Jambi. metode pengambilan sampelnya adalah probality sampling dengan teknik simple random sampling. Sampel pada penelitian ini 
adalah seluruh siswa kelas XI MIPA 2 sebagai kelas eksperimen dan siswa kelas XI MIPA 3 sebagai kelas kontrol pada semester genap tahun ajaran 2016/2017.

Agar mendapat sampel yang representatif dilakukan langkah-langkah sebagai berikut:

1. Mengambil nilai ulangan biologi siswa kelas XI MIPA SMA Negeri 1 Muaro Jambi.

2. Menghitung nilai rata-rata dan standar deviasi hasil belajar biologi untuk masing-masing kelas sampel pada populasi.

3. Melakukan uji normalitas.

4. Melakukan uji homogenitas

Selanjutnya, dilakukan pengambilan kelas sampel secara undian. Adapun langkah-langkahnya adalah:

1. Membuat daftar berisi kelas populasi yang akan diambil sebagai sampel.

2. Memberi kode berupa angka-angka untuk semua yang akan diselidiki.

3. Menulis kode tersebut masing-masing pada selembar kertas kecil.

4. Menggulung setiap kertas kecil berkode tersebut.

5. Memasukkan gulungan kertas tersebut dalam gelas.

6. Mengocok baik-baik gelas tersebut.

7. Mengambil satu persatu gulungan tersebut sejumlah kebutuhan (satu kelas eksperimen dan satu kelas kontrol).

Variabel bebas dalam penelitian ini adalah Model Pembelajaran Picture and Picture yang dipadukan dengan Strategi pembelajaran Everyone Is A Teacher Here. Variabel terikat dalam penelitian ini adalah hasil belajar biologi kelas XI SMAN 1 Muaro Jambi. Data kuantitatif Dalam penelitian ini adalah merupakan gambaran dari hasil belajar dalam ranah kognitif. Data kualitatif merupakan data yang menggambarkan hasil belajar siswa pada ranah apektif dan psikomotor. Data ini diperoleh dari hasil lembar pengamatan tentang aspek apektif dan lembar kerja pengamatan serta instrumen aktivitas belajar siswa. Data kualitatif disajikan dalam bentuk data deskriptif tidak dilambangkan dengan angka. Sumber data dalam penelitian ini adalah siswa kelas XI (sebelas) SMAN 1 Muaro Jambi yang terdaftar pada tahun ajaran 2016/2017 dijadikan sebagai subjek penelitian.

\section{Hasil}

\section{Uji Coba Instrumen Penelitian}

Uji coba intrumen penelitian dilakukan untuk mengetahui validitas, reliabilitas, tingkat kesukaran, dan daya beda soal tes yang digunakan untuk mengambil data hasil belajar pada kedua sampel yang akan diberikan sebagai post test siswa. Uji coba instrumen soal dilakukan di kelas XI SMA Negeri 11 Kota Jambi.

\section{Analisis Validitas Soal Uji Coba}

Hasil uji coba soal yang akan digunakan sebagai instrumen penelitian selanjutnya dihitung validitasnya. Analisis validitas soal ujicoba dijelaskan pada tabel 3. 


\begin{tabular}{|c|c|c|c|}
\hline Harga $r_{x y}$ & $\begin{array}{c}\text { Kriteria } \\
\text { Pengukuran }\end{array}$ & Nomor Soal & Jumlah \\
\hline $\begin{array}{c}0,80<r_{x y} \leq \\
1,00\end{array}$ & $\begin{array}{l}\text { Validitas sangat } \\
\text { tinggi }\end{array}$ & - & - \\
\hline $\begin{array}{c}00,60< \\
r_{x y} \leq 0,80\end{array}$ & Validitas tinggi & 32 & 1 \\
\hline $\begin{array}{c}0,40< \\
r_{x y} \leq 0,60\end{array}$ & Validitas sedang & $\begin{array}{c}5,7,10,11,14,16,29,30,33,3 \\
4\end{array}$ & 10 \\
\hline $\begin{array}{c}0,20< \\
r_{x y} \leq 0,40\end{array}$ & Validitas rendah & $\begin{array}{c}1,4,12,15,17,20,23,24,25,2 \\
6,27,33\end{array}$ & 12 \\
\hline $\begin{array}{c}0,00< \\
r_{x y} \leq 0,20\end{array}$ & $\begin{array}{l}\text { Validitas sangat } \\
\text { rendah }\end{array}$ & 3,21 & 2 \\
\hline$r_{\text {xynegative }}$ & Tidak valid & $2,6,, 8,9,13,18,19,22,28,31$ & 10 \\
\hline
\end{tabular}

Tabel 3 Validitas Soal Hasil Uji coba

Berdasarkan Tabel 3 kriteria validitas tinggi ada 1 butir soal, untuk kriteria validitas sedang ada 10 butir soal, untuk kriteria validitas rendah ada 12 butir soal, untuk kriteria validitas sangat rendah ada 2 butir soal, dan terdapat 10 butir soal dengan kriteria tidak valid. Untuk soal yang memiliki kriteria validitas sangat rendah diperbaiki sehingga dapat digunakan untuk soal post test sedangkan butir soal yang tidak valid tidak dipakai untuk soal post test pada saat penelitian.

\section{Analisis Reliabilitas}

Setelah menentukan validitas butir soal, selanjutnya menghitung reliabilitas dengan menggunakan rumus K-R 20 pada soal ujicoba yang diperoleh $\mathrm{r}_{\mathrm{K}-\mathrm{R} 20}=$ 0,42 . Hal ini menunjukkan bahwa reliabilitas tes hasil belajar yang dijadikan instrument. dalam penelitian memiliki kriteria cukup.

Analisis Tingkat Kesukaran

Indeks kesukaran hasil soal uji coba dapat dijelaskan pada Tabel 4 berikut:

Tabel 4 Indeks Kesukaran Soal Uji coba

\begin{tabular}{|c|c|c|c|}
\hline Harga P & $\begin{array}{c}\text { Kriteria } \\
\text { Pengukur } \\
\text { an }\end{array}$ & Nomor Soal & $\begin{array}{c}\text { Jumla } \\
\mathbf{h}\end{array}$ \\
\hline $0,00-0,19$ & $\begin{array}{c}\text { Sangat } \\
\text { Sukar }\end{array}$ & 15 & 1 \\
\hline $0,20-0,39$ & Sukar & $5,8,16,25$ & 4 \\
\hline $0,40-0,59$ & Sedang & $2,4,10,11,12,13,20,22,23,27,28,32$ & 12 \\
\hline $0,60-0,79$ & Mudah & $\begin{array}{c}1,3,6,7,9,14,17,18,19,21,24,26,29,30,3 \\
1,33,34,35\end{array}$ & 18 \\
\hline $0,80-1,00$ & $\begin{array}{c}\text { Sangat } \\
\text { Mudah }\end{array}$ & - & \\
\hline
\end{tabular}


Dari Tabel 4 terlihat ada 1 soal yang memiliki kriteria pengukuran sangat sukar, ada 4 soal yang memiliki kriteria pengukuran sukar, 12 soal yang memiliki kriteria pengukuran sedang, dan ada 18 soal yang memiliki pengukuran mudah. Sementara untuk kriteria soal sangat mudah tidak ada.

\section{Analisis Daya Beda Soal} berikut:

Perhitungan daya beda soal ujicoba dapat dilihat pada lampiran dan tabel 5

\begin{tabular}{|c|c|c|c|}
\hline Harga D & Kriteria Pengukuran & Nomor Soal & Jumlah \\
\hline $0,71-1,00$ & Baik sekali & - & - \\
\hline $0,41-0,70$ & Baik & $5,14,25$ & 3 \\
\hline $0,21-0,40$ & Cukup & $\begin{array}{c}3,7,9,11,12,19,21,24 \\
, 27,29,30,32,34\end{array}$ & 13 \\
\hline $0,00-0,20$ & Jelek & $\begin{array}{c}1,2,4,6,8,10,13,15,1 \\
6,17,18,20,\end{array}$ & 19 \\
& & $\begin{array}{c}22,23,26,28,31,33,3 \\
5 .\end{array}$ & \\
\hline
\end{tabular}

Tabel 5 Daya Beda Hasil Soal Uji Coba

Tabel 5 dapat dilihat bahwa, ada 3 soal yang memilki daya beda baik, dan ada 13 soal yang memiliki daya beda cukup, sedangkan 19 soal memiliki daya beda jelek. Secara. Untuk soal yang mempunyai daya beda soal yang jelek digunakan dalam penelitian ini terlebih dahulu diperbaiki. Sehingga soal yang digunakan sebagai tes kognitif adalah sebanyak 25 butir soal yaitu item soal nomor 1,3,4,5,7,10,11,12, 14,15, 16,17,20,21,23,24,25,26,27,29,30,32,33,34,35.

\section{Hasil Analisis Pada Ranah Kognitif}

Hasil belajar pada aspek kognitif diperoleh dari hasil tes akhir siswa yang dilakukan pada akhir pokok bahasan. Nilai rata-rata hasil belajar biologi siswa pada aspek kognitif kelas eksperimen dan kelas kontrol, dapat dilihat pada tabel 6.

Tabel 6. Nilai rata-rata hasil belajar siswa

\begin{tabular}{|c|l|c|c|}
\hline No. & \multicolumn{1}{|c|}{ Kelas } & Jumlah Siswa & $\begin{array}{c}\text { Hasil Belajar } \\
\text { Kognitif }\end{array}$ \\
\hline 1. & Eksperimen & 31 & 72,52 \\
\hline 2. & Kontrol & 31 & 64,13 \\
\hline
\end{tabular}

Berdasarkan Tabel 6diketahui bahwa nilai rata rata tes akhir siswa untuk kelas Eksperimen adalah 72, 52 sedangkan kelas kontrol adalah 64,13. Hal ini menunjukkan hasil belajar pada kelas ekperimen lebih tinggi daripada kelas kontrol.

\section{Uji Normalitas Pada Ranah Kognitif}

Hasil belajar yang diperoleh dari kelas eksperimen dan kelas kontrol kemudian dilakukan uji normalitas dengan menggunakan uji Liliefors diperoleh hasil seperti tabel 7 . 
Tabel 7 Uji Normalitas hasil belajar siswa Aspek Kognitif

\begin{tabular}{|c|c|c|c|c|}
\hline Kelas & Jumlah Siswa & $\mathbf{L}_{\mathbf{o}}$ & $\mathbf{L}_{\mathbf{t}}$ & Keterangan \\
\hline Eksperimen & 31 & 0,1513 & 0,1591 & Normal \\
\hline Kontrol & 31 & 0,1574 & 0,1591 & Normal \\
\hline
\end{tabular}

Dari 7 terlihat bahwa $\mathrm{L}_{\mathrm{o}}<\mathrm{L}_{\text {tabel. }}$. Berdasarkan tabel tersebut maka disimpulkan bahwa kedua sampel berdistribusi normal.

\section{Uji Homogenitas Pada Ranah Kognitif}

Uji Homogenitas pada penelitian ini dilakukan dengan menggunakan uji Fisher. Setelah di lakukan uji homogenitas terhadap hasil belajar kognitif maka diperoleh hasil seperti tabel berikut:

Tabel 8 Uji Homogentitas hasil belajar aspek kognitif

\begin{tabular}{|c|c|c|c|}
\hline Kelas & $\mathbf{L}_{\mathbf{0}}$ & $\mathbf{L}_{\mathbf{t}}$ & Keterangan \\
\hline $\begin{array}{c}\text { Eksperimen dan } \\
\text { Kontrol }\end{array}$ & 0,5607 & 1,84 & Homogen \\
\hline
\end{tabular}

Berdasarkan tabel 7 diperoleh $F_{\text {hitung }}=0,5607$ dan $F_{\text {tabel }}=1,84$ dapat dilihat bahwa $F_{\text {hitung }}<F_{\text {tabel }}$ sehingga dapat disimpulkan data tersebut homogen.

\section{Uji Hipotesis Pada Ranah Kognitif}

Pengujian hipotesis bertujuan untuk mengetahui pengaruh penerapan model pembelajaran Picture and Picture yang dipadukan dengan strategi pembelajaran aktif Everyone Is A Teacher Here (ETH) terhadap hasil belajar biologi siswa. Pengujian hipotesis dilakukan setelah menentukan normalitas dan homogenitas dari hasil belajar siswa pada aspek kognitif pada kedua kelas sampel.

Adapun hipotesis statistiknya adalah:

$$
\begin{aligned}
& \mathrm{H}_{0}: \mu_{1}=\mu_{2} \\
& \mathrm{H}_{0}: \mu_{1} \neq \mu_{2}
\end{aligned}
$$

$\mathrm{H}_{0}$ : Model pembelajaran Picture and Picture yang dipadukan dengan strategi pembelajaran aktif Everyone Is A Teacher Here (ETH) tidak berpengaruh terhadap hasil belajar biologi siswa pada aspek kognitif.

$\mathrm{H}_{1}$ : Model pembelajaran Picture and Picture yang dipadukan dengan strategi pembelajaran aktif Everyone Is A Teacher Here (ETH) berpengaruh terhadap hasil belajar biologi siswa pada aspek kognitif.

Pengujian hipotesis hasil belajar kognitif selanjutnya dibandingkan antara $\mathrm{t}_{\text {hitung }}$ yang diperoleh dengan $\mathrm{t}_{\text {tabel. }}$. Hasil pengujian hipotesis dapat dilihat pada tabel 8 berikut : 
Tabel 8 Uji Hipotesis Hasil Belajar Kognitif

\begin{tabular}{|l|l|c|c|c|c|c|}
\hline Kelas & $\boldsymbol{N}$ & $\boldsymbol{S}_{\boldsymbol{i}}^{\mathbf{2}}$ & $\boldsymbol{S}_{\boldsymbol{g a b}}$ & $\boldsymbol{t}_{\text {hitung }}$ & $\boldsymbol{t}_{\text {tabel }}$ & Keterangan \\
\cline { 1 - 4 } $\begin{array}{l}\text { Eksperi } \\
\text { men }\end{array}$ & 31 & 39,19 & \multirow{2}{*}{7,38} & 4,55 & 1,671 & $\mathrm{H}_{1}$ diterima \\
\cline { 1 - 3 } Kontrol & 31 & 63,52 & & & & \\
\hline
\end{tabular}

Pengujian lanjut pada kelas eksperimen dengan kelas kontrol memiliki t hitung $=4,55$ dibandingkan dengan $\mathrm{t}_{\text {tabel }}$ dengan $\mathrm{dk}=\mathrm{n}_{1}+\mathrm{n}_{2}-2=31+31-2=60$, dengan taraf kesalahan 5\% maka diperoleh $t_{\text {tabel }}=1,671$. Dari hasil uji-t menunjukkan bahwa maka $\mathrm{t}_{\text {hitung }}>\mathrm{t}_{\text {tabel }}$ yaitu, 4,55 > 1,671 dan $\mathrm{H}_{1}$ diterima. Sehingga dapat disimpulkan bahwa model pembelajaran Picture and Picture yang dipadukan dengan strategi pembelajaran aktif Everyone Is A Teacher Here (ETH) berpengaruh terhadap hasil belajar biologi siswa kelas XI MIPA SMA Negeri 1 Muaro Jambi pada ranah kognitif.

\section{Pembahasan}

Hasil belajar pada aspek kognitif diperoleh dari hasil tes akhir siswa yang dilakukan pada akhir pokok bahasan. Hasil belajar pada aspek kognitif di dapatkan dengan memberikan tes berupa soal objektif sebanyak 25 butir. Soal tes yang diberikan tersebut terlebih dahulu sudah di uji validitas, reliabilitas tingkat kesukaran dan daya beda soal. Berdasarkan tes tersebut diperoleh nilai rata rata hasil belajar aspek kognitif yaitu pada kelas ekperimen 72,52 dan kelas kontrol 64,13. Hasil yang diperoleh tersebut kemudian di uji normalitas dan homogenitas selanjutnya dilakukan uji lanjut dengan menggunakan uji-t. Hal ini bertujuan untuk menguji hipotesis penelitian. Berdasarkan uji-t tersebut diperoleh bahwa $t_{\text {hitung }}>t_{\text {tabel }}$ yaitu 4,55 $>1,671$ sehingga $\mathrm{H}_{1}$ diterima dapat dilihat seperti gambar di bawah ini.

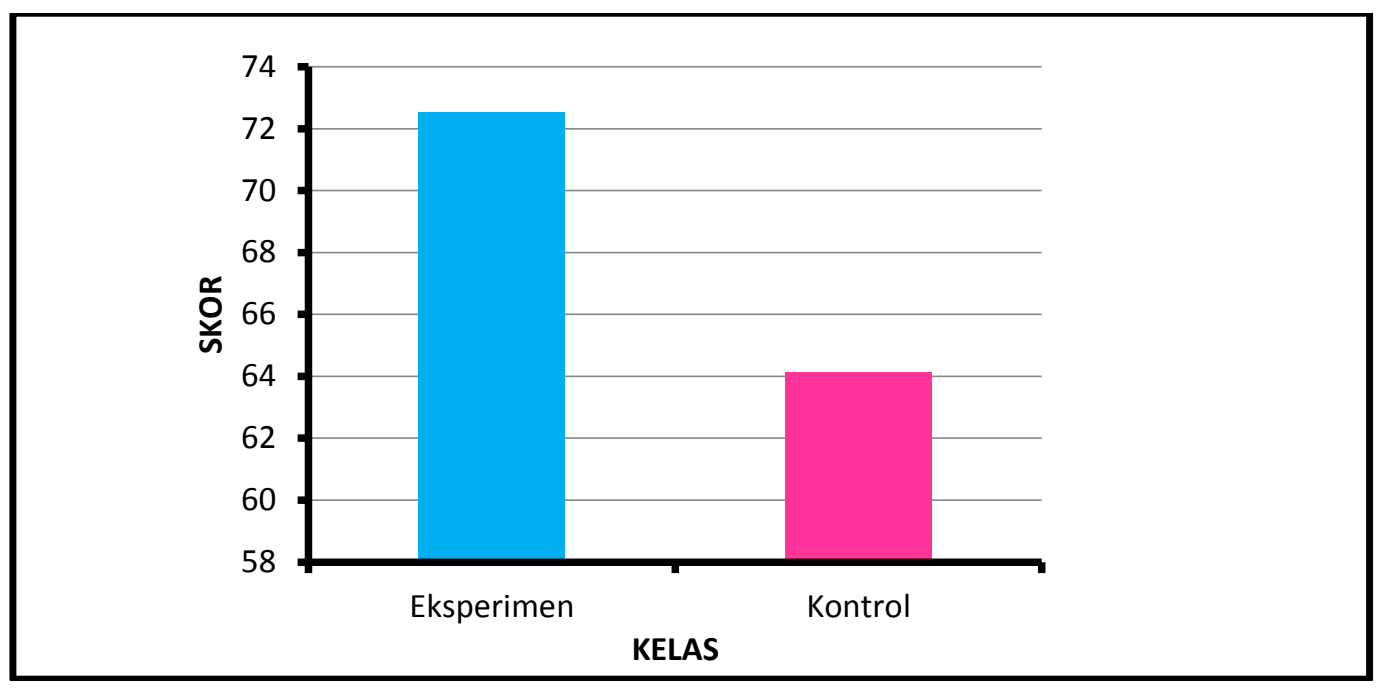

Gambar 1. Diagram Hasil Belajar Aspek Kognitif Kelas Sampel

Gambar tersebut menjelaskan bahwa terdapat perbedaan rata-rata hasil belajar siswa yang belajar dengan menggunakan Model Pembelajaran Picture and 
Picture dipadukan dengan Strategi pembelajaran Aktif Everyone Is A Teacher Here (ETH) dan yang belajar melalui metode ceramah pada aspek kognitifnya. Model pembelajaran Picture and Picture merupakan model pembelajaran yang tepat dalam meningkatkan hasil belajar kognitif. Model pembelajaran Picture and Picture adalah model pembelajaran yang dapat membantu siswa dalam memahami materi pembelajaran namun kurang mendorong siswa dalam belajar aktif. Sementara Keaktifan seorang siswa di dalam belajar biasanya berpengaruh terhadap hasil belajar siswa.

Strategi pembelajaran Everyone Is A Teacher Here (ETH) bertujuan untuk dapat meningkatkan hasil belajar siswa karena dengan strategi pembelajaran ini dapat mendorong anak untuk belajar aktif. Dalam penelitian ini, peneliti memadukan model pembelajaran Picture and Picture dipadukan dengan strategi pembelajaran Everyone Is A Teacher Here (ETH). Menurut Zaini,dkk (2008:60), penggunaan strategi pembelajaran Everyone Is A Teacher Here mengharapkan peserta didik yang selama ini tidak mau terlibat akan ikut serta dalam proses pembelajaran secara aktif. Keterlibatan dari setiap peserta didik diharapkan akan memberikan pengaruh yang besar terhadap perkembangan pengetahuan peserta didik. Berdasarkan hal tersebut pemaduan strategi pembelajaran Everyone Is A Teacher Here (ETH) dengan model pembelajaran Picture and Picture diharapkan dapat membantu siswa didalam memahami pembelajaran dan siswa dapat belajar aktif.

Dengan demikian dapat disimpulkan bahwa penerapan model pembelajaran Picture and Picture dipadukan dengan strategi pembelajaran Everyone Is A Teacher Here (ETH) berpengaruh terhadap hasil belajar siswa kelas XI MIPA SMA Negeri 1 Muaro Jambi pada aspek kognitif. Hal ini dengan diperolehnya rata-rata hasil belajar kognitif kelas eksperimen lebih tinggi daripada rata-rata hasil belajar kelas Kontrol.

\section{Kesimpulan}

Berdasarkan hasil analisis data dan uji hipotesis yang dilakukan, dapat disimpulkan bahwa model pembelajaran Picture and Picture yang dipadukan dengan Strategi pembelajaran Aktif Everyone Is A Teacher Here (ETH) berpengaruh terhadap hasil belajar biologi siswa kelas XI MIPA SMA Negeri 1 Muaro Jambi pada ranah kognitif dengan $t_{\text {hitung }}=4,55$ dan $t_{\text {tabel }}=1,671$.

\section{Saran}

Berdasarkan hasil kesimpulan maka peneliti mmberisakan saran sebagai berikut:

1. Guru diharapkan dapat menerapkan Model pembelajaran Picture and Picture dipadukan dengan Strategi pembelajaran Aktif Everyone Is A Teacher Here dalam proses pembelajaran biologi. Hal dikarenakan model pembelajaran Picture and Picture yang dipadukan dengan Strategi pembelajaran Everyone Is A Teacher Here dapat meningkatkan keaktifan yang akan berpengaruh pada hasil belajar yang meningkat.

2. Peneliti berharap adanya penelitian lanjutan mengenai pengembangan media dengan menggunakan Model pembelajaran Picture and Picture yang dipadukan dengan strategi pembelajaran Everyone Is A Teacher Here (ETH) pada materi biologi yang lain. 


\section{Daftar Rujukan}

Arikunto, Suharsimi. 2013. Dasar Dasar Evaluasi Pendidikan Edisi 2. Jakarta : Bumi Aksara

Aryaningrum, Kiki. 2015. Pengaruh Strategi Pembelajaran Everyone Is A Teacher Here Terhadap Hasil Belajar Siswa Pada Mata Pelajaran IPS SMP Negeri 1 Belitang III Oku Timur. Jurnal Ilmiah CIVIS. V (2).

Aunurrahman. 2013 . Belajar dan Pembelajaran. Bandung: Alfabeta.

Daryanto, 2010. Belajar dan Mengajar. Bandung: Yrama Widya.

Fatmawati Sri, Ariesta, Darmaji, Putri. 2015. Desain Laboratorium Skala Mini Untuk Pembelajaran Sains Terpadu. Yogyakarta: Deepublish.

Ferdinand Fiktor \& Ariebowo Moekti .2007. Praktis Belajar Biologi. Jakarta: Visindo Media Persada

Firmasyah, Agus Mawardi dan Umar Riandi. 2006. Mudah dan Aktif Belajar Biologi. Bandung: PT Setia Purna Invest.

Gali Irwan, \& Amalia. 2015. Alat Analisis Data. Yogyakarta: Andi Offset.

Garnasih, \& Arry Setya. 2012. Intisari Biologi. Jakarta: Laskar Aksara.

Gulo. W. 2000. Metodologi Penelitian. Jakarta: Grasindo.

Hamalik, Oemar. 2005. Kurikulum dan Pembelajaran Edisi I. Jakarta:Bumi Aksara

Hamdi Saepul dan Bahruddin. 2014. Metode Penelitian Kuantitatif Aplikasi dalam Pendidikan. Yogyakarta: Deepublish.

Handayani, Bintari, \& Lisdiana. 2013. Penerapan Model Pembelajaran Picture and Picture berbantuan specimen pada materi Invertebrata. Unnes. J.Biol.Educ . II (3).

Lie, A. 2014. Cooperative Learning: Mempraktikkan Cooperative Learning Di Ruang Kelas. Jakarta: Grasindo.

Majid, Abdul. 2014. Strategi Pembelajaran. Bandung: PT Remaja Rosdakarya.

Majid Abdul. 2014. Penilaian Autentik Proses Dan Hasil Belajar. Bandung: PT Remaja Rosdakarya.

Margono. 2005. Metodologi Penelitian Pendidikan. Jakarta: PT Rineka Cipta.

Ngalimun. 2014. Strategi dan Model Pembelajaran. Yogyakarta: Aswaja Pressindo.

Pebriana Risa Gede, Ketut Dibia, Ndara Tanggu Renda. 2017. Penerapan Model Pembelajaran Picture and Picture untuk meningkatkan hasil aktivitas dan hasil belajar IPA Kelas V. Mimbar PGSD. VII (1).

Pratomo Nur Eko, Alvi Rosyidi, Puguh Karyanto.2015. Hasil Belajar Biologi Ranah Kognitif Ditinjau dari Model Everyone Is A Teacher Here dan Minat Belajar Siswa Kelas XI di SMA Negeri 1 Sukoharjo. Pendidikan Biologi. IV (3).

Pratiwi, Sri maryati. Srikini, Suharno,\& Bambang. 2006. Biologi untuk SMA/MA. Jakarta: Erlangga

Purwanto. 2014. Evaluasi Hasil Belajar. Yogyakarta: Pustaka Pelajar

Riyono dan Retnoningsih. 2015. Efektivitas Model Pembelajaran Picture and Picture dengan Strategi Inkuiri Terhadap Motivasi dan Hasil Belajar Siswa. Unnes.J.Biol.Educ. IV (2). 
Rusman. 2014. Model Model Pembelajaran: Mengembangkan Profesionalisme Guru Edisi Kedua . Jakarta: Rajawali Press.

Sanjaya, Wina. 2006. Strategi Pembelajaran Berorientasi Standar Proses Pendidikan. Jakarta: Kencana

Sari Melda, Supriyadi \& Sudirman. 2014. Penerapan Strategi Active Learning Tipe Everyone Is A Teacher Here Untuk Meningkatkan Hasil Belajar. Jurnal Pedagogi II (5).

Sari, Yessi. 2015. Evaluasi Pendidikan. Yogyakarta: Deepublish

Shoimin, Aris. 2014. 68 Model Pembelajaran Inovatif dalam Kurikulum 2013. Yogyakarta:Ar-ruzz Media.

Silberman, Mel. 2009. Active Learning (Strategi Pembelajaran Aktif). Yogyakarta: Pustaka Insan Madani.

Suardi. 2015. Belajar dan Pembelajaran. Yogyakarta: Deepublish.

Sudjana. 2005. Metoda Statistika. Bandung: Tarsito

Sugiyono. 2014. Metode Penelitian Kuantitatif Kualitatif dan R\&D. Bandung: Alfabeta

Suprijono, Agus. 2015. Cooperative Learning (Teori \&Aplikasi PAIKEM). Yogyakarta: Pustaka Pelajar.

Susanto, Ahmad. 2013. Teori belajar pembembelajaran di sekolah dasar. Jakarta: kencana

Suyono dan Hariyanto. 2014. Belajar dan Pembelajaran. Bandung: Remaja Rosdakarya.

Syulasmi, Ami. 2015. Diakses pada 11 oktober 2016. Sistem Pernapasan.

http://file.upi.edu/Direktori/FPMIPA/JUR._PEND._BIOLOGI/195408281986122

AMMI_SYULASMI/BIOLOGI_UMUM/Bioum._POWERPOINT/BAB_VI I_SISTEM_PERNAPASAN.pdf

Uno, Hamzah. 2014. Model Pembelajaran. Jakarta: Bumi Aksara

Uno Hamzah, \& Mohamad Nurdin. 2014. Belajar dengan Pendekatan PAIKEM. Jakarta: Bumi Aksara.

Warsono, \& Hariyanto. 2012. Pembelajaran Aktif Teori dan Asesmen. Bandung: Remaja Rosdakarya.

Wicaksono Andri, Syaefudin Mohamad, Qalbi Nur, Nasir Mohamad.2016. Teori Pembelajaran Bahasa. Edisi Revisi. Yogyakarta: Garudhawaca.

Zaini Hisyam, Munthe Bermawy, Aryani Ayu Sekar. 2008. Strategi Pembelajaran Aktif. Yogyakarta: Pustaka Insan Madani. 
Armalina

20 Annaba : Jurnal Pendidikan Islam 